\title{
THE FUTURE OF LANGUAGES AND A CULTURAL IMMERSION
}

\section{Author: James Hugo and Taylor Ambrose}

\begin{abstract}
There are some studies conducted showing that children, from birth until they reach seven, are in the stage that they could acquire language easier. The ability of an individual to acquire languages will slowly decrease as they surpass puberty. How can adults learn language effectively and faster? We are now living in am era of globalization, every country and culture has become connected whether it is in business, education and other fields. There is a need to be knowledgeable, not in just our local tongue, but also in other languages. It has be come a necessity to be able to be a part of the community, get better career opportunities, and therefore succeed. There are different methods on how we can improve our skills of acquiring languages. Different aides like CDs, DVDs, books, dictionaries and magazines can be bought easily in bookstores. But experts have agreed that the most important method is by submerging ourselves of the language's culture. There are numerous experts who agree that the best way and most efficient method of teaching language would be what is called as "language immersion." Reading grammar and vocabulary books are indeed important in order to increase language knowledge. But it is practice and exposure that you would find most helpful when learning a new language. For example, if you would go abroad and live there, then it would be inevitable that you would pick up the language. You are exposed to different aspects of culture that uses the language, like television, movies, radio, restaurants, museums, transportation and other public places.
\end{abstract}

Keyword: ESL Student Language; Cultural Immersion; Education;

\section{Introduction}

Everything changes. There are cultural changes brought about by discovery, invention, diffusion, colonization and rebellion. If language is said to be rooted or transmitted in culture, therefore, it would be safe to say that language also changes. Languages change when its phonetic, morphological, semantic, syntactic and other features also change.

All languages change. Linguists have examined that the existing languages are based or derived from the older languages. This would show how society and social changes would have impact or influence on language. For example, before Latin was part of the National Curriculum. But as of the present, nobody spoke it since it was perceived to be old and archaic. But linguists cannot deny its major influence on present languages. 
Before, there was a prevailing idea that English would emerge as a world language. But according to language British experts, people are more likely to learn not only English but other languages, as well. English has become not the leading language, but a second language, according to the Journal Science. What we are heading to is not a monolingual culture but into a multilingual one. Language diversity is something which can be waiting for us in the future.

Let's take the internet for example. It has become multilingual. In 1995, 90\% of it was in English. When 2000 arrived, 75\% was in English. When 2003 arrived, English was not only the language visible on the internet. Chinese and Africans were already online. This simple example could reflect that the world in becoming more multilingual.

Some linguists like Stephen Anderson from Yale recognizes that multilingualism is something normal or natural. This is the normal condition of the people since culture and society is also diversified. However it is not correct to say that because society is multilingual in nature, then we should avoid learning other languages and stay with what language we know. Actually, learning other languages has become an advantage in an era of globalization. This would be an advantage when you are after a better education and career opportunity.

Another interesting future that language would face would be the development of technology. There are different translation programs that are able to translate documents in 6 major languages. Although, it is not a hundred percent perfect, the versions being released commercially are improving.

These programs would soon pave the future where it is possible to talk into different languages where computer programs would help in translations and conversations. Although, computers where programs like these could be installed may not be portable enough, it would eventually be in a few years time. But these programs would not be replacing translators, they would still be needed to learn and create the programs.

There are experts who say that identifying the dominant language in the future is difficult. Since everybody has its biases. Even the claim that multilingual would be the language of the future, is being disputed. Some still claim that English would be the dominant language. The bottom line is that world language is changing and nothing can stop that. Changes in communication are happening nowadays. All of these because of the changing demographic 
trends, technology and international communication. These changes are manifesting not only what we are speaking but also in what we are writing. Languages would not stop developing because society is undergoing change. Some languages may go extinct but this is to give birth to new ones.

Language immersion will keep learning language balanced. Language is something reflected by the people's culture, thus, to understand the language it would be best to understand the ideas and concepts behind it by immersing in the culture. Aside from that, it keeps learning interactive and fun. You do not have to pour over boring texts for hours and still unable to retain anything. Language immersion does not mean you would have to Spain to learn Spanish and go to France and fluently speak French. There are different ways to immerse ourselves in other cultures without spending too much on the airfare.

- You could start by renting foreign films and listening to different radio programmes using the language of your interest. For example, if you want to learn how to speak Spanish, then telenovelas would be a great way to get acquainted with the language. Telenovelas play a major role in Latin America's pop culture. There are teachers who would testify that students would get involved in the dramas that they do not even realize that they are slowly improving their Spanish skills.

- Foreign films are also great avenues for language immersion. They are interesting, easy to access and of course in the language that you would like to learn.

- If you are not a big fan of foreign dramas and films, then you could certainly learn a lot from foreign sports. You could learn from the announcers and fans, just like in drama, you get involved with the sports that you keep track of it and gradually understanding what those announcers are actually reporting.

- Radio has played a major role in language acquisition. There are online radios from different parts of the globe which you can listen to. You may find it difficult in the beginning but later on, you will start to identify more and more words and eventually learn the language. 
- Eating in foreign restaurants would also allow you to get acquainted to foreign dishes and how they were pronounced. Some restaurants would even include foreign performances while dining.

Learning different languages could be done in ways that you do not have to spend too much or leave the country. But if you feel that travelling will boost your experience and education, then go ahead. There are many options that you could choose from, make sure that you will be picking out the most practical.

\section{Discussion}

The Successful Teaching of the Adult English Language Learner

\begin{tabular}{|l|}
\hline \multicolumn{1}{|c|}{ Questions } \\
\hline What countries are your students from? \\
\hline What language(s) do they speak? \\
\hline What are their educational backgrounds? \\
\hline Who are your students? \\
\hline Why are they taking your class? What are their immediate goals? \\
\hline
\end{tabular}

The first step to the successful teaching of the adult ESL student is to find out some basic information about your students and their motives for attending your class. Teaching ESL to adults is not like teaching ESL to children.

\section{What are the differences?}

One major difference is life experience. Adult students come to the classroom with diverse cultures, knowledge, and frequently an extensive vocabulary because they have more life experiences than children. Thus, adults should be assisted in drawing upon their backgrounds as they practice literacy skills. Building on what already is known makes the tasks of reading, writing, listening, and speaking more consequential and less threatening than a curriculum that does not take into account what the student brings to the learning setting. 
We've talked about life experience. Can you think of another difference between teaching a child and an adult? Motivation.

Adult students are goal oriented and highly motivated. They attend class of their own free will and at some personal and financial sacrifice. Absences are due to family and economic obligation rather than a lack of motivation.

\section{Do children have immediate life goals that need to be satisfied?}

Adult students usually have very specific and immediate goals. Many are not looking to some long-range academic achievement. They need English today, to get a job tomorrow.

Children are naturally curious, but...Do they see themselves as students? Does the adult ESL student?

Many adult ESL students have a poor self-concept. They do not see themselves as students. The undereducated adult is especially convinced they cannot or they do not know how to learn.

Two questions for you, Teacher:

1. What is your role in the community? Are you...

\begin{tabular}{|l|l|l|l|l|l|l|l|}
\hline Parent & Relative & Friend & Employee & Customer & Patient & Client & Parishioner \\
\hline
\end{tabular}

2. Do you have many and varied life responsibilities and roles?

If you have countless roles and varied responsibilities, then you can relate to your adult student. You can understand that as parents, workers, friends, and relatives we have many roles that must be fulfilled. We have busy schedules. When we take a class, our schedules would naturally prevent us from going to class at certain hours due to time or distance.

Outside the classroom, our students have many diverse interests. Therefore it is important to bring these interests to class in the form of relevant class activities. The experiences of our students can serve as fodder for our lessons and make our activities more applicable.

Who is the typical adult ESL student? 
You will be disappointed to learn that there is no typical adult ESL student. Every student in a class will have a wide range of backgrounds, skills, and interests. Listed below are some of the more important differences:

1. Literacy or the Low Level Student - one of the most important differences among adult students is whether they can read or write in their native language. If students are literate in their native language, learning another language is much easier than for the non-literate or low-literate student. Why? Because (most) literate students already understand the sound/symbol correlation, have a grammar base and many other skills that are essential to learning a language.

2. Formal Education - you will more than likely have students whose educational backgrounds range from those with advanced degrees from a foreign university to students with little or no formal education. One important thing for you to remember is not to underestimate the intelligence of your students. Most are smarter than their ability to speak English would seem to indicate.

You may also experience a wide range of ages that will require you to use diverse activities in the classroom in order to reach all of your students. In this case, you can be most effective by grouping students by level and doing many activities in small groups.

What has motivated your students to come to class?

- You may have students who are very eager to learn English so they can advance in their jobs. Their motivation is the dollar.

- You may have students who are required by their employer to attend classes but who do not really care about English at all. Their motivation may be peripheral.

- You may have the student who has been pressed by family or friends to learn English.

- Others may have made a decision to learn English for self-improvement. This may be true of moms who attend classes because their children are in school and they want to be able to talk to their children's teacher.

How can you motivate your students? 
You will need to find out what your students really want. Regardless of the reasons why adult students enter our classrooms, genuine concern, an enjoyable class, and a sense of progress will increase motivation once students are there.

Different theories abound regarding how people learn best and how to teach. Whether you're a seasoned teacher or a novice, as you work with your students and exercise your skills, you will discover what works and what does not. You will need to be flexible enough to continually modify your original plans to meet new student needs and interests. In other words, always have a back-up plan! Have that extra game, exercise or activity available. Don't worry. You'll find the methods that work best for your students.

1. Would you want a class composed of reading sounds, words out of context or work on isolated grammar problems without immediate application? Yes? No?

2. Would you like to receive worksheets and other assignments which drill meaningless language elements and language skills in isolated contexts? Yes? No?

It is imperative that we maintain student interest in our classes. So, if you require that students read sounds (the alphabet), words out of context (vocabulary lists), or drill grammar in isolated situations (He is/are single), then your students may not return to your classroom. Adults need immediate application for what they are taught. Our students come to us with a wealth of experiences and represent a wide range of educational backgrounds. They should have input into how teaching and learning progresses.

Have you ever taught (or have been a student) in a classroom that was too hot? Too cold? How did you feel? Yes? No? Put yourself in your student's place. If you are uncomfortable in a classroom that is too hot or too cold, then you know that student will be also. Adults learn best when they feel comfortable in the learning environment.

\section{How can we make students comfortable?}

Listen to your students. Interest in the class will remain high if students actively participate. Adults learn best when what they are learning can be applied to the world outside the classroom. Have you ever sat inactively and listened someone explain something? Do you remember what it was? (Think about the question for a moment.) Yes? No? How did you feel? 
Now, think back to a time when you were actively engaged in learning something as you were taught. How did you feel then? Complete the following statement in your own words. There is no right or wrong answer. I felt...

It's a good idea to use techniques and materials that have been chosen on the basis of the student's skill level, needs, goals, and learning style. For these reasons, we need to use a variety of learning activities in our teaching - what might work for some, might not work for others. Each student is an individual. If we do not meet a student's needs, they will not return to class. Our students are more directed and involved in instruction when what they are learning is useful and meaningful and can be applied to their everyday lives.

It has been said that people retain:

- $10 \%$ of what they read

- $20 \%$ of what they hear

- $30 \%$ of what they see

- $50 \%$ of what they see and hear

- $90 \%$ of what they say and do

\section{Given the above, what implications do these statements have for teaching adult students?}

Actively involve your students in the learning process. Find out your students' needs and wants, and plan your lessons accordingly. Don't ignore the "teachable moment" when for example, a student raises a question/concern outside what you're currently teaching or there is a breaking news topic. Make sure activities directly relate to students' lives. Adult students want more than to sit and watch as you wax philosophically on, for example, count versus noncount nouns.

Keep in mind that the adult student has a plethora of lifetime experiences that $\mathrm{s} / \mathrm{he}$ brings to the ESL classroom. As our students learn from us, we learn from them. It's a collaborative learning process. S/he may not be able to understand, speak, read or write English so use these experiences as a basis for your lessons. 


\section{References}

Brenneis, D. (2018). The matrix of language: Contemporary linguistic anthropology. Routledge.

Bitchener, J., Young, S., \& Cameron, D. (2005). The effect of different types of corrective feedback on ESL student writing. Journal of second language writing, 14(3), 191-205.

Cooper, R. L., \& Spolsky, B. J. (Eds.). (2019). The influence of language on culture and thought: essays in honor of Joshua A. Fishman's sixty-fifth birthday. Walter de Gruyter GmbH \& Co KG.

Csomay, E., \& Prades, A. (2018). Academic vocabulary in ESL student papers: A corpus-based study. Journal of English for Academic Purposes, 33, 100-118.

Cunningham, K. J. (2019). Student perceptions and use of technology-mediated text and screencast feedback in ESL writing. Computers and Composition, 52, 222-241.

Dewi, E. W., Nurkamto, J., \& Drajati, N. A. (2019). EXPLORING PEER-ASSESSMENT PRACTICE IN GRADUATE STUDENTS'ACADEMIC WRITING. LLT Journal: A Journal on Language and Language Teaching, 22(1), 58-65.

Gallagher, P., Mckinlay, E., Pullon, S., \& McHugh, P. (2019). Student perceptions of cultural immersion during an Interprofessional programme. Journal of Interprofessional Care, 33(2), 264-266.

Habibi, H. (2018). PROTECTING NATIONAL IDENTITY BASED ON THE VALUE OF NATION LOCAL WISDOM. International Journal of Malay-Nusantara Studies, 1(2), 24-40.

Ho, L. M. E. (2018). Improving ESL formative assessment practices and student learning via multi-staged peer assessment of oral presentations (Doctoral dissertation, University of Bristol).

Hu, G. (2019). 3 Culture and Peer Feedback. Feedback in Second Language Writing: Contexts and Issues, 45.

Larson, S., \& Hugo, J. (2019, December 30). Creative Cultural Industries: A Great Economic Capital for the Social, Political and Economic Development of Africa. Retrieved from osf.io/eb8zr

Li, Y., \& Flowerdew, J. (2018). What really is the relationship between plagiarism and culture?: Some thoughts from the Chinese context. In Student Plagiarism in Higher Education (pp. 140-156). Routledge.

McAdams, D. P. (2019). Identity, Narrative, Language, Culture, and the Problem of Variation in Life Stories. Evolutionary Studies in Imaginative Culture, 3(1), 77-84.

Nuroh, E. Z., \& Astutik, Y. (2018). Peer Review: A Case Study of an ESL Student Learning English in an English Speaking Country.

Radecki, P. M., \& Swales, J. M. (1988). ESL student reaction to written comments on their written work. System, 16(3), 355-365.

Seymour, L. (2018). Cultural immersion and the development of cultural sensitivity. Australian Midwifery News, 18(4), 39. 
Shufflebarger Snell, A. M. (2019). A dialogic approach to exploring culture in community-based adult ESL classrooms. TESOL Journal, e00450.

Stuart, C. (2018). ESL writers in the Mainstream Classroom: Cultivating a Culture of Success.

Yuan, S. (2019). Developing Students' Cultural Understanding in the Dual Language Immersion Program (Doctoral dissertation, The University of North Carolina at Chapel Hill). 